\title{
Auditor Liability and Business Investment*
}

\author{
CHIAWEN LIU, National Taiwan University
}

TAYCHANG WANG, National Taiwan University

\begin{abstract}
We model a firm's investment decision, an auditor's effort-rendering behavior, audit fees, and prices of the firms under two auditor liability rules: strict liability and negligence liability. We show that an auditor's effort level is socially optimal under strict liability, while it is not generally so under negligence liability. Furthermore, both the firm owner's expected benefit and the audit fee are higher under strict liability than under negligence liability. We define the legal error under negligence liability as the difference between the assessed audit effort (that is, the estimate of audit effort made by the court) and the actual audit effort and prove that the greater the variance of the legal error, the more incentive an auditor has to exert effort under negligence liability compared with strict liability. Finally, the number of investments being undertaken could be higher under strict liability because more firm owners are willing to hire auditors to go public.
\end{abstract}

Keywords Auditor liability; Investment; Negligence liability; Strict liability

JEL Descriptors D41, K13, M42

\section{Responsabilité du vérificateur et investissements}

\section{Condensé}

Les avantages possibles pour les vérificateurs du passage des normes de responsabilité délictuelle aux normes de responsabilité stricte ont récemment fait l'objet d'un débat chez les chercheurs en droit (Hamdani, 2003 ; Coffee, 2004). En fait, la responsabilité stricte suscite depuis longtemps l'intérêt des chercheurs et des tribunaux (voir, par exemple, Shavell, 1980, 1987 ; Hardy, 1994 ; Ginsburg, 1995 ; Schwartz, 1997 ; Zhang et Thoman, 1999 ; Ewert, Feess et Nell, 2000 ; Yen, 2000 ; Partnoy, 2001). Sous le régime de la responsabilité délictuelle, le vérificateur ne doit compenser les pertes des investisseurs que si le tribunal conclut qu'il a manqué à son devoir de diligence raisonnable. Sous le régime de la responsabilité stricte, le vérificateur est responsable des pertes des investisseurs, qu'il soit ou non coupable de faute professionnelle dans la réalisation de la vérification. Le but des auteurs de la présente étude

* Accepted by Steven Huddart. We would like to thank two anonymous referees for helpful comments and suggestions. We also wish to thank Steven Huddart (associate editor) and seminar participants at the 2004 American Accounting Association annual meeting for helpful suggestions. We gratefully acknowledge the National Science Council, ROC, for financial support (NSC 89-2416-H-155-033). 
est de procéder à l'examen analytique des équilibres, dans un cadre vérificateur-clientinvestisseur, sous les régimes de la responsabilité stricte et de la responsabilité délictuelle. Les auteurs s'intéressent en particulier au nombre prévu de projets d'investissement qui seront réalisés.

Les recherches comptables précédentes sur la responsabilité du vérificateur ont porté principalement sur l'effort de vérification. Peu d'études analytiques ont sondé la relation entre la responsabilité du vérificateur et l'investissement. Schwartz (1997), Shibano (2000), et Chan et Wong (2002) font notablement exception. Bien que Shibano (2000), Chan et Wong (2002) et les auteurs de la présente étude explorent tous l'incidence de la responsabilité du vérificateur sur l'investissement, les régimes de responsabilité étudiés dans les deux premiers cas diffèrent de ceux qu'analysent les auteurs de la présente étude. Shibano (2000) se penche sur les répercussions sur l'investissement de la hausse des indemnités que les vérificateurs sont susceptibles de devoir verser. Chan et Wong (2002) analysent la relation entre l'étendue de la responsabilité du vérificateur à l'égard des tiers et l'investissement. Dans la présente étude, les auteurs comparent le nombre de projets d'investissement réalisés sous le régime de la responsabilité stricte et sous celui de la responsabilité délictuelle. Leur modèle est semblable à celui de Schwartz (1997), à quelques différences près. Schwartz a principalement pour but de concevoir un cadre juridique susceptible d'induire des niveaux socialement optimaux d'investissement et d'effort de vérification. Elle ne compare pas les situations d'équilibre sous les régimes de la responsabilité stricte et de la responsabilité délictuelle. Les auteurs, quant à eux, analysent et comparent, à l'équilibre, l'effort de vérification, les honoraires de vérification, le choix du vérificateur par le propriétaire de l'entreprise et les avantages qu'il espère en tirer, et le nombre prévu de projets d'investissement réalisés sous les deux régimes de responsabilité.

En 1992, les Six Grands cabinets d'expertise comptable de l'époque ont publié une prise de position commune dans laquelle ils affirmaient : « Si le coût des services fournis par les vérificateurs de même que les placeurs, les avocats et autres défendeurs souvent prospères augmente pour les sociétés, il sera plus onéreux pour celles-ci de mobiliser les capitaux nécessaires. Les occasions pour les investisseurs s'en trouveront diminuées [...] » (Arthur Andersen \& Co., Coopers \& Lybrand, Deloitte \& Touche, Ernst \& Young, KPMG Peat Marwick et Price Waterhouse, 1992 - traduction). Le contexte de l'étude des auteurs permet d'explorer l'incidence du passage du régime de responsabilité du vérificateur de la responsabilité délictuelle à la responsabilité stricte, en particulier sur les décisions d'investissement des sociétés.

Les résultats de cette étude révèlent que le régime de la responsabilité stricte procure un avantage espéré supérieur au propriétaire de l'entreprise et des honoraires de vérification plus élevés au vérificateur que le régime de la responsabilité délictuelle. De plus, les auteurs supposent que le tribunal fait erreur dans l'observation du niveau de l'effort de vérification. En d'autres termes, l'effort de vérification évalué par le tribunal correspond à la somme de l'effort réel et d'une variable aléatoire désignée « erreur judiciaire ». Les auteurs montrent comment la variance de l'erreur judiciaire influe sur l'intensité relative de l'effort de vérification selon les deux régimes de responsabilité. En outre puisque l'avantage que prévoit tirer le propriétaire de l'entreprise d'une mission de vérification est plus élevé sous le régime de la responsabilité stricte, certains propriétaires d'entreprise qui s'abstiennent de faire appel public à l'épargne sous le régime de la responsabilité délictuelle choisissent de le faire sous 
le régime de la responsabilité stricte. Cette situation pourrait donc mener à la croissance du nombre de projets d'investissement réalisés sous le régime de la responsabilité stricte.

En conséquence, les résultats des auteurs entrent quelque peu en contradiction avec les affirmations des Six Grands évoquées ci-dessus. La responsabilité accrue du vérificateur ne rend pas nécessairement plus difficile pour les entreprises la tâche de mobiliser les fonds nécessaires et, par conséquent, ne la prive pas d'occasions d'investissement. Au contraire, il est possible que davantage d'occasions d'investissement soient saisies par les entreprises. Le raisonnement sur lequel repose cette hypothèse est le suivant : l'affirmation des Six Grands ne tient compte que du fait que la responsabilité accrue du vérificateur entraînera des honoraires de vérification plus élevés que certaines entreprises ne pourront donc pas se permettre. Elle ne tient pas compte du fait que, lorsqu'il évalue une occasion d'investissement, l'investisseur prend en considération non seulement le rendement net de l'investissement lui-même, mais aussi les indemnités que pourrait devoir verser le vérificateur. La responsabilité accrue du vérificateur augmente le montant prévu de l'indemnisation des dommages et rend donc l'occasion d'investissement plus attrayante.

De plus, les résultats obtenus par les auteurs peuvent être appliqués à la prédiction des conséquences du changement de régime de responsabilité du vérificateur dans divers cadres juridiques. Dans les pays affichant une faible variance de l'erreur judiciaire, la responsabilité délictuelle fournit au vérificateur moins d'incitatifs à déployer un effort important. Le passage à la responsabilité stricte augmenterait donc les encouragements à l'effort pour les vérificateurs. En revanche, dans les pays affichant une forte variance de l'erreur judiciaire, l'incertitude liée au système juridique sous le régime de la responsabilité délictuelle fournit au vérificateur un incitatif à déployer davantage d'efforts pour éviter un jugement défavorable possible. En conséquence, le passage à la responsabilité stricte aura pour effet d'atténuer la propension des vérificateurs à déployer des efforts.

Enfin, il convient de noter que le marché de la vérification est concurrentiel par hypothèse, de sorte que les vérificateurs obtiennent un profit économique nul à l'équilibre. Un vérificateur n'aura, a priori, aucune préférence pour un régime de responsabilité ou l'autre. Donc, la situation envisagée dans la présente étude ne permet pas d'analyser les conséquences du changement de régime de responsabilité sur le profit du vérificateur et ne peut expliquer l'attitude du vérificateur à l'égard de différents régimes de responsabilité. Pour étudier la préférence du vérificateur pour un régime de responsabilité, il faut savoir comment l'avantage de la vérification se répartit entre le propriétaire de l'entreprise et le vérificateur, en supposant la légitimité de l'hypothèse d'un marché concurrentiel des premiers appels publics à l'épargne où les investisseurs ne partageront pas les avantages supplémentaires découlant de la réalisation d'un investissement. L'on pourrait formuler des hypothèses précises au sujet des pouvoirs de négociation relatifs des deux parties ou des nombres relatifs de vérificateurs et d'entreprises de chaque catégorie, qui compliqueraient sensiblement l'analyse. Les auteurs proposent le traitement rigoureux de cette question dans de prochaines études.

\section{Introduction}

Recently, there has been a debate among legal researchers as to whether it is beneficial to shift to strict liability standards for auditors. For example, Hamdani (2003, 55) states that, "despite the apparent consensus that insufficient deterrence of gatekeepers, such as accountants, is to blame for debacles like Enron, there has been 
virtually no attempt to go down the simple path of making gatekeeper liability more stringent - by moving in the direction of strict liability, for example". However, Hamdani contends that strict liability is a potentially costly tool for inducing gatekeepers to prevent client wrongdoing. On the other hand, Coffee (2004) suggests that gatekeepers face strict liability with modified penalties. As a matter of fact, strict liability has long appealed to both academics and the courts (see, e.g., Shavell 1980, 1987; Hardy 1994; Ginsburg 1995; Schwartz 1997; Zhang and Thoman 1999; Ewert, Feess, and Nell 2000; Yen 2000; Partnoy 2001).

Under negligence liability, an auditor has to compensate for the investors' loss only if the court concludes that the auditor failed to exercise due diligence. Under strict liability, an auditor is liable for the investors' loss, whether or not the auditor is negligent in performing the audit. The purpose of this paper is to examine analytically the equilibria under strict liability and negligence liability in an auditor-client-investor framework. In particular, we focus on the expected number of investment opportunities being undertaken.

Previous accounting literature on auditor liability has focused mainly on the audit effort. ${ }^{1}$ Few analytical studies have explored the relation between auditor liability and business investment. Schwartz (1997), Shibano (2000), and Chan and Wong (2002) are notable exceptions. Schwartz (1997) studies the impact of damage measures on investments. She shows that investors will overinvest if damages are measured on the basis of investors' actual investment level. However, with a legal regime consisting of a strict liability rule and an appropriately chosen damage measure that is unrelated to the actual investment, the socially optimal levels of investment and audit effort can be achieved. Shibano (2000) explores the effects of increasing the amount of auditors' expected liability payment on investment. The results indicate that increasing auditors' liability payment could lead the auditor to adopt a conservative reporting strategy, which reduces the number of new investments. Chan and Wong (2002) analyze the relationship between the scope of auditor liability to third parties and investment. They find that the investment level is higher when the scope is confined to the users specifically identified in the engagement than when the scope includes those whose reliance on the audit report is foreseen, which in turn is higher than when the scope is broadened to include third parties whom the auditor could reasonably foresee as recipients of the audit report for general business purposes.

Although Shibano (2000), Chan and Wong (2002), and this paper all explore the impact of the auditor liability on investment, the liability regimes examined by the first two papers are different from the one in this paper. Our model is similar to but differs from Schwartz 1997. The main purpose of Schwartz 1997 is to design a legal scheme that can induce the socially optimal levels of investment and audit effort. She does not compare the equilibria under strict liability and negligence liability. However, we analyze and contrast equilibrium audit efforts, audit fees, the firm owner's auditor-hiring decisions and expected benefits, and the expected numbers of investments being undertaken under the two liability regimes.

In 1992, the then Big 6 issued a joint statement of position, which stated, "If companies must pay higher costs for services provided both by auditors and by 
underwriters, attorneys and other frequent deep pocket defendants, it will be more expensive for them to raise needed capital. Opportunities for investors will be reduced" (Arthur Andersen \& Co., Coopers \& Lybrand, Deloitte \& Touche, Ernst \& Young, KPMG Peat Marwick, and Price Waterhouse 1992, 22). With our setting, it is possible to explore the impact of the change in the auditor liability regime, from negligence liability to strict liability, in particular, on the investment decisions of the companies.

As we will see later, the strict liability regime can be viewed as a special case of the negligence liability regime where an auditor is always judged negligent when a corporate failure occurs. Since audit procedures are not perfect in detecting error and an auditor's effort is not easily observable, it is possible that, in practice, the court tends to judge an auditor with hindsight and conclude that an auditor did not perform enough audit procedures. Besides, as mentioned in the 1992 joint statement of position, "Prohibitive legal costs, the unpredictable outcome of a jury trial and the risk of being liable for the full damages compel even blameless defendants to race each other to the settlement table. ... However, controlling risk by settling when you did nothing wrong becomes a very expensive strategy for 'winning' the liability game" (Arthur Andersen \& Co. et al. 1992, 20). The legal environment where an innocent defendant is forced to settle a case for a large sum of money is in fact not much different from the strict liability regime that we model. ${ }^{2}$

In this paper, we assume that the court observes audit effort with an error. In other words, the court-assessed audit effort is the sum of the actual effort and a random variable, which is coined as "legal error". We show how the variance of the legal error affects the relative magnitudes of audit effort levels under the two liability regimes. In addition, we show that the firm owner gets a higher expected benefit and the auditor earns a higher audit fee under strict liability than under negligence liability. Furthermore, because the firm owner's expected benefit from an audit is higher under strict liability, some firm owners who do not go public under negligence liability choose to do so under strict liability. Hence, this could lead to a greater number of investments being undertaken under strict liability.

Consequently, our results are somewhat contradictory to the Big 6's claim mentioned above. Higher auditor liability does not necessarily make it harder for firms to raise the funds needed and hence lose investment opportunities. On the contrary, it is possible that more firms' investment opportunities are undertaken. The rationale behind this is that the Big 6's claim considers only that the increase in auditor liability will induce higher audit fees and hence some firms would find it unaffordable. However, their argument ignores that, when evaluating an investment opportunity, an investor considers not only the net return of the investment opportunity itself but also the auditor's damage payment. Higher auditor liability raises the investor's expected damage compensation and hence makes the investment opportunity more attractive.

The rest of this paper is organized as follows. Section 2 presents the model. Section 3 analyzes and contrasts the equilibria under strict liability and negligence liability. Section 4 concludes the paper. The appendix contains proofs. 


\section{The model}

Consider a one-period model. There are three kinds of risk-neutral players: firms' original owners, outside investors, and auditors. At the beginning of the period, each firm has an investment opportunity. The return on the investment will be realized at the end of the period. An investment requires an initial outlay $I$ and will generate a high return $G$ with probability $p \in[0,1]$ and a low return $B$ with probability $1-p$, where $G>I>B$. It is not assumed that all firms are identical. That is, firms can differ in $G, I, B$, or $p$. All $G, I, B$, and $p$ are assumed to be common knowledge. We leave out the firm subscript for brevity. Besides, to simplify the presentation, we denote the ex ante expected return to a firm's investment opportunity as $E \equiv p G+(1-p) B .^{3}$

Assume that an original owner has no funds and hence has to decide whether to sell his firm (that is, the investment opportunity) to an outside investor. If he does not sell, the investment opportunity is forgone. If he chooses to sell, he has to issue an audited statement about the prospective return on the investment opportunity. ${ }^{4}$ In reality, an auditor expresses an opinion on whether the client's historical financial statements are fairly presented in conformity with generally accepted accounting principles. Most often, an investor's prediction of a firm's future performance is based on the audited historical financial statements. To simplify the analysis, we subsume this relationship within a larger framework that links an audit opinion directly to the firm's prospects. Without loss of generality, we assume that all firm owners claim to have a high-return project.

After being hired, an auditor chooses an unobservable effort level $x \in[-\infty, \infty]$. The cost of audit effort is $\mathrm{C}(x)$ with $\mathrm{C}^{\prime}(x)>0$ and $\mathrm{C}^{\prime \prime}(x)>0$. To simplify the model, we assume that an auditor does not make a type I error and will report truthfully what he has found so that the issue of auditor independence will not confound the result. ${ }^{5}$ Consequently, when the true return of the investment opportunity is $G$, an auditor will not discover any evidence against the owner's claim and will issue an unqualified opinion. When the true return of the investment opportunity is $B$, the probability that an auditor gathers evidence against the firm owner's claim and issues a qualified opinion is $\mathrm{q}(x) \in[0,1]$ with $\mathrm{q}^{\prime}(x)>0$; the probability that an auditor incorrectly issues an unqualified opinion for a low-return project is $1-\mathrm{q}(x)$.

At the end of the period, if the realized return is low and yet the audit report is unqualified, the investor will file suit against the auditor. ${ }^{6}$ In this paper, we consider two auditor liability regimes: strict liability and negligence liability. Under strict liability, an auditor is liable for the investor's damage for an erroneously unqualified opinion, whether he is negligent or not. Under negligence liability, an auditor is required to pay a damage award only if the auditor is judged negligent in performing the audit. Because the audit effort is unobservable, the effort level assessed by the court is imprecise and is assumed to be a random variable $\tilde{Q}$ with $\tilde{Q}=x+\tilde{\epsilon} . \tilde{\epsilon}$ is normally distributed with mean 0 and variance $\sigma^{2}$ and is interpreted as the legal error under negligence liability. Let $\mathrm{h}(\tilde{Q} \mid x)$ denote the density function of $\tilde{Q}$, given the actual effort level $x$. That is, $\mathrm{h}(\tilde{Q} \mid x)=e^{-(\tilde{Q}-x)^{2} /\left(2 \sigma^{2}\right) /}$ $(\sqrt{2 \pi} \sigma)$. Due to the vagueness of the due care standard, we use $\mathrm{n}(\tilde{Q})$ to denote 
the probability that an auditor will be judged negligent, which is decreasing in the court-assessed audit effort level $\tilde{Q}$ at a decreasing rate. That is, $\mathrm{n}^{\prime}(\tilde{Q})<0$ and $\mathrm{n}^{\prime \prime}(\tilde{Q})>0 .{ }^{7}$ As in Schwartz 1997, the definition of damages in this paper is based on an out-of-pocket damage measure, $I-B$. Therefore, if the realized return is low and the audit report is unqualified, the expected damage payment is $I-B$ under strict liability and is

$(I-B) \int_{-\infty}^{\infty} \mathrm{h}(\tilde{Q} \mid x) \cdot \mathrm{n}(\tilde{Q}) d \tilde{Q}$

under negligence liability. In addition, if the realized return is low and the report is qualified, the auditor is not liable for the investor's loss. Finally, if the realized return is high, the auditor is free of any legal responsibility because the investor does not suffer any loss.

We assume that the capital market is competitive and the discount rate is zero. Therefore, given the audit report, the equilibrium price of the firm is the conditional expectation of the future net cash flow from purchasing the investment opportunity, which equals the sum of the conditional expectation of the net return from the investment itself and the damage award from the auditor. In addition, we assume that the audit market is competitive and contingent audit fees are prohibited. Thus, in equilibrium, an auditor's expected profit is zero and the audit fee equals the auditor's expected cost from accepting the engagement, which consists of the cost of the audit effort and the expected liability payment. Figure 1 summarizes the decision tree of the model.

\section{The equilibria under strict liability and under negligence liability}

In this section, we first establish the socially optimal audit effort and investment as benchmarks. We then show that the equilibrium under strict liability is socially optimal. Finally, we analyze the equilibrium under negligence liability and compare it with the equilibrium under strict liability.

\section{Socially optimal audit effort and investment}

Social welfare is defined as the sum of the expected payoffs to the original firm owner, the new investor, and the auditor. When an auditor is hired, the original firm owner's expected payoff equals the expected selling price of the firm net of the audit fee. The new investor's expected payoff from purchasing the firm is the conditional expected net return from the investment itself and from the auditor's liability payment, minus the purchase price of the firm. The auditor's expected payoff equals the audit fee minus the cost of audit effort and the expected liability payment. Since the audit fee, the price of the firm, and the auditor's liability payment are mere transfers among the three kinds of players, they do not affect the social welfare. Hence, when an auditor is hired, social welfare is the unconditional expected net return from the investment itself,

$$
[p+(1-p)(1-\mathrm{q}(x))]\{[p G+(1-p)(1-\mathrm{q}(x)) B] /[p+(1-p)(1-\mathrm{q}(x))]-I\},
$$




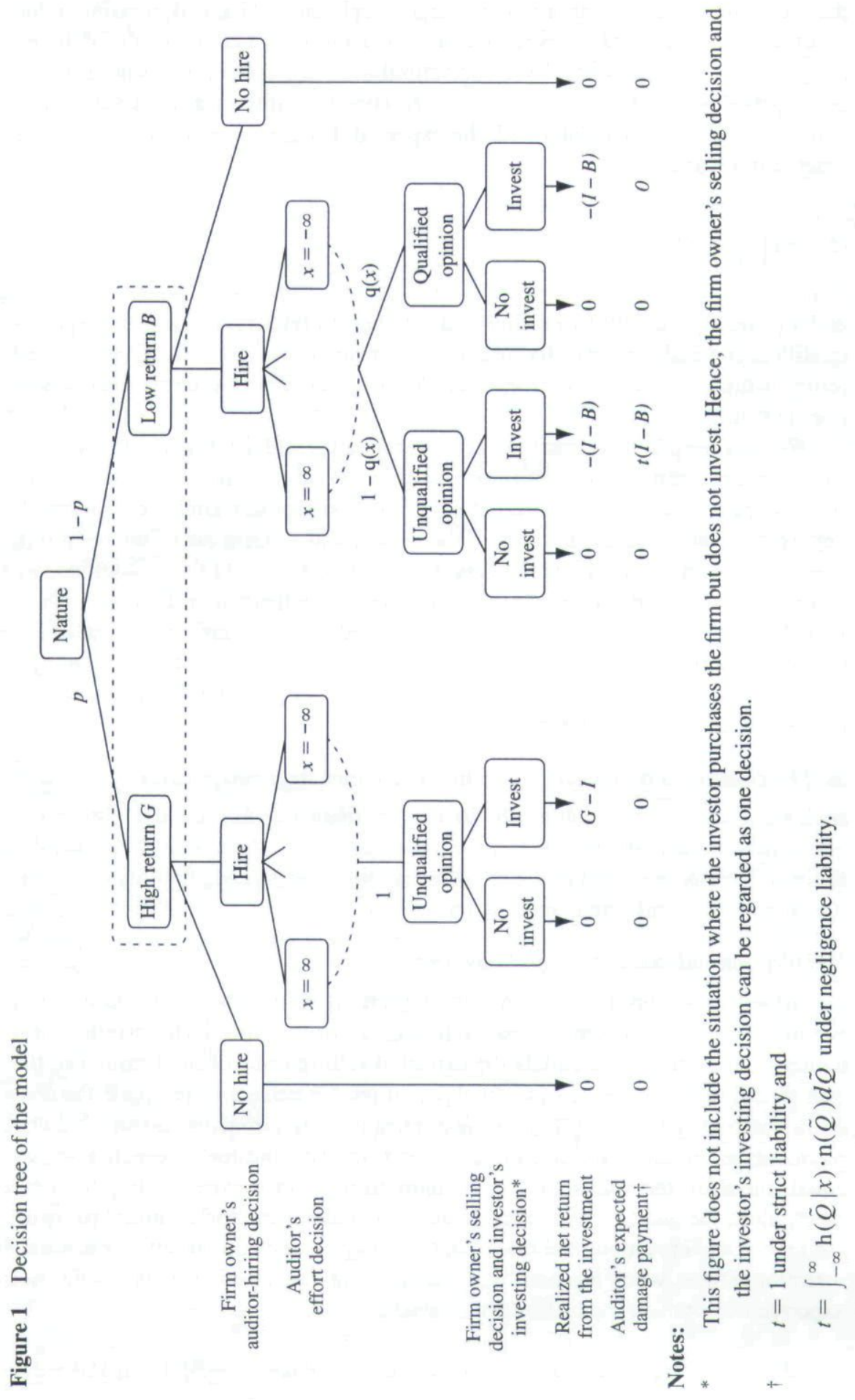


minus the cost of audit effort, $\mathrm{C}(x)$, and can be further restated as follows:

$E-I+\mathrm{q}(x)(1-p)(I-B)-\mathrm{C}(x)$

Therefore, the socially optimal level of audit effort $x^{*}$ is the one that satisfies the first-order condition in maximizing (1). ${ }^{8}$ That is,

$\mathrm{C}^{\prime}\left(x^{*}\right)=\mathrm{q}^{\prime}\left(x^{*}\right)(1-p)(I-B)$

From the viewpoint of social welfare, for firms with $E-I+\mathrm{q}\left(x^{*}\right)(1-p)$ $(I-B)-\mathrm{C}\left(x^{*}\right) \geq 0$, an auditor should be hired. Furthermore, the investment opportunity should be carried out if the audit report is unqualified. Otherwise, the investment opportunity should not be undertaken.

\section{The equilibrium under strict liability}

Since the audit market is competitive and the audit fee is not contingent, the audit fee is treated as exogenous when an auditor determines his effort level. Hence, from an auditor's decision-making perspective, expected-profit maximization is equivalent to expected-cost minimization. Under strict liability, an auditor's expected cost is the cost of audit effort $\mathrm{C}(x)$ plus the expected damage payment $(1-p)(1-\mathrm{q}(x))(I-B)$. That is, an auditor's effort decision under strict liability is:

$\min _{x} \mathrm{C}(x)+(1-p)(1-\mathrm{q}(x))(I-B)$

Let $x_{s l}$ denote an auditor's effort choice under strict liability. The first-order condition of (3) indicates that $x_{s l}$ satisfies the following equation:

$\mathrm{C}^{\prime}\left(x_{s l}\right)=\mathrm{q}^{\prime}\left(x_{s l}\right)(1-p)(I-B)$

In the following, "inherent risk" means the probability $1-p$ that an investment project will produce a low return. The concept of "detection risk" can be captured by the derivative of the audit quality function for a given level of audit effort $\mathrm{q}^{\prime}(\cdot)$. That is, a low $\mathrm{q}^{\prime}(\cdot)$ implies a not-so-effective audit process and hence a high detection risk. From (4), we know that an auditor's effort decision depends on the inherent risk and the detection risk. A high inherent risk means that it is more likely for an unqualified opinion to be unwarranted. Hence, ceteris paribus, the higher the firm's inherent risk, the higher the auditor's incentive to exert effort. On the other hand, a high detection risk means that an auditor's effort is ineffective in avoiding an audit failure. Hence, ceteris paribus, the higher the detection risk, the less the auditor's incentive to exert effort. Furthermore, an auditor's effort decision also depends on the amount of liability payment $I-B$. The more an auditor has to pay, the more incentive an auditor has to exert effort to avoid an audit failure. Finally, comparing (4) with (2), it is obvious that the effort level chosen by an auditor under strict liability is also the socially optimal one (that is, $x_{s l}=x^{*}$ ). 
We next analyze a firm owner's auditor-hiring decision. Under the assumption of competitive capital and audit markets, the expected price of a firm is the sum of the expected net return from the investment itself and the damage award from the auditor, and can be expressed as

$$
\begin{array}{r}
{\left[p+(1-p)\left(1-\mathrm{q}\left(x_{s l}\right)\right)\right]\left\{\left[p G+(1-p)\left(1-\mathrm{q}\left(x_{s l}\right)\right)(B+I-B)\right] /\right.} \\
\left.\left[p+(1-p)\left(1-\mathrm{q}\left(x_{s l}\right)\right)\right]-I\right\},
\end{array}
$$

which can be further rearranged as $E-I+(1-p)(I-B)$. The audit fee equals an auditor's expected cost, $\mathrm{C}\left(x_{s l}\right)+(1-p)\left(1-\mathrm{q}\left(x_{s l}\right)\right)(I-B)$. Therefore, the original firm owner's expected benefit from an audit under strict liability is:

$$
\begin{aligned}
E-I+(1-p)(I-B)-\mathrm{C}\left(x_{s l}\right)-(1-p)\left(1-\mathrm{q}\left(x_{s l}\right)\right)(I-B) \\
=E-I+\mathrm{q}\left(x_{s l}\right)(1-p)(I-B)-\mathrm{C}\left(x_{s l}\right) .
\end{aligned}
$$

An auditor will be hired if and only if $E-I+\mathrm{q}\left(x_{s l}\right)(1-p)(I-B)-\mathrm{C}\left(x_{s l}\right) \geq 0$. Since both capital and audit markets are competitive, each of the new investors and the auditors earns zero expected profit in equilibrium and hence the firm owner's expected benefit from an audit equals the social welfare as expressed in (1). A firm owner's expected benefit from an audit achieves its maximum under strict liability because $x_{s l}=x^{*}$. We document the above discussions regarding the equilibrium under strict liability in Proposition 1.

PROPOSITION 1. Under strict liability, in equilibrium,

(a) for firms with $E-I+\mathrm{q}\left(x_{s l}\right)(1-p)(I-B)-\mathrm{C}\left(x_{s l}\right)<0$, the owners will not hire auditors and hence their investment projects will be forgone;

(b) for firms with $E-I+\mathrm{q}\left(x_{s l}\right)(1-p)(I-B)-\mathrm{C}\left(x_{s l}\right) \geq 0$,

(i) the owners will hire auditors;

(ii) the auditor's effort level $x_{s l}$ satisfies $\mathrm{C}^{\prime}\left(x_{s l}\right)=\mathrm{q}^{\prime}\left(x_{s l}\right)(1-p)(I-B)$ and is socially optimal;

(iii) the audit fee equals $\mathrm{C}\left(x_{s l}\right)+(1-p)\left(1-\mathrm{q}\left(x_{s l}\right)\right)(I-B)$;

(iv) the probability of receiving an unqualified opinion is $p+(1-p)$ $\left(1-\mathrm{q}\left(x_{s l}\right)\right)$; the price of the firm with an unqualified opinion is $\left[p G+(1-p)\left(1-\mathrm{q}\left(x_{s l}\right)\right) I\right] /\left[p+(1-p)\left(1-\mathrm{q}\left(x_{s l}\right)\right)\right]-I$, which is greater than $E-I$, and the firm's investment opportunity will be undertaken;

(v) the probability of receiving a qualified opinion is $\mathrm{q}\left(x_{s l}\right)(1-p)$; the price of the firm with a qualified opinion is zero and the investment opportunity is forgone. 


\section{Negligence liability versus strict liability}

An auditor's expected damage payment is

$$
(1-p)(1-\mathrm{q}(x))(I-B) \int_{-\infty}^{\infty} \mathrm{h}(\tilde{Q} \mid x) \cdot \mathrm{n}(\tilde{Q}) d \tilde{Q}
$$

under negligence liability. Thus, an auditor's effort decision under negligence liability is:

$$
\min _{x} \mathrm{C}(x)+(1-p)(1-\mathrm{q}(x))(I-B) \int_{-\infty}^{\infty} \mathrm{h}(\tilde{Q} \mid x) \cdot \mathrm{n}(\tilde{Q}) d \tilde{Q}
$$

Let $x_{n l}$ denote an auditor's effort choice under negligence liability. The first-order condition of (5) means that $x_{n l}$ satisfies the following equation: ${ }^{9}$

$$
\begin{aligned}
\mathrm{C}^{\prime}\left(x_{n l}\right)=(1-p)(I-B)\left[\mathrm{q}^{\prime}\left(x_{n l}\right) \int_{-\infty}^{\infty} \mathrm{h}\left(\tilde{Q} \mid x_{n l}\right) \cdot \mathrm{n}(\tilde{Q}) d \tilde{Q}\right. \\
\\
\quad-\left(1-\mathrm{q}\left(x_{n l}\right)\right) \int_{-\infty}^{\infty} \frac{\partial h\left(\tilde{Q} \mid x_{n l}\right)}{\partial x} \cdot \mathrm{n}(\tilde{Q}) d \tilde{Q}
\end{aligned}
$$

Recall that the legal error is defined as the error term $\tilde{\epsilon} \sim N\left(0, \sigma^{2}\right)$. The greater the variance of the legal error, $\sigma^{2}$, the less precise the court is in assessing an auditor's effort level. Equation (6) implies that an auditor's effort level under negligence liability depends on the variance of the legal error, in addition to the factors that affect an auditor's effort under strict liability (that is, the amount of liability payment, inherent risk, and detection risk). The relation is stated in Lemma 1.

LEMMA 1.

$$
\partial\left[\mathrm{q}^{\prime}(x) \int_{-\infty}^{\infty} \mathrm{h}(\tilde{Q} \mid x) \cdot \mathrm{n}(\tilde{Q}) d \tilde{Q}-(1-\mathrm{q}(x)) \int_{-\infty}^{\infty} \partial \mathrm{h}(\tilde{Q} \mid x) / \partial x \cdot \mathrm{n}(\tilde{Q}) d \tilde{Q}\right] /
$$

$\partial \sigma>0$.

That is, an auditor's effort level under negligence liability is increasing in the standard deviation (and hence variance) of the legal error.

A large variance of the legal error can result in a relatively high or low courtassessed effort $\tilde{Q}$ for a given actual effort level $x$ and thus can result in a relatively high or low probability that an auditor is judged liable, $\mathrm{n}(\tilde{Q})$. Recall that $\mathrm{n}(\tilde{Q})$ is decreasing in the court-assessed effort at a decreasing rate. Thus, a relatively high court-assessed effort does not provide an auditor with a benefit that is high enough to compensate for the harm from a relatively low court-assessed effort. Consequently, the larger the variance of the legal error, the higher the expected damage award an auditor has to pay when an audit failure occurs and the more benefit an 
auditor can capture from avoiding being judged liable by working harder. Therefore, we get a somewhat counterintuitive result that an auditor's incentive to make an effort under negligence liability is increasing in the variance of the legal error.

Comparing (6) with (4), we know that the audit effort level under negligence liability is more or less than under strict liability. Audit effort under negligence liability is greater than under strict liability (that is, $x_{n l}>x_{s l}$ ) if and only if

$\mathrm{q}^{\prime}\left(x_{s l}\right) \int_{-\infty}^{\infty} \mathrm{h}\left(\tilde{Q} \mid x_{s l}\right) \cdot \mathrm{n}(\tilde{Q}) d \tilde{Q}-\left(1-\mathrm{q}\left(x_{s l}\right)\right) \int_{-\infty}^{\infty} \partial \mathrm{h}\left(\tilde{Q} \mid x_{s l}\right) / \partial x \cdot \mathrm{n}(\tilde{Q}) d \tilde{Q}$

Lemma 1 indicates that the left-hand side of the inequality is increasing in $\sigma$. Hence, it is more likely that

$\mathrm{q}^{\prime}\left(x_{s l}\right) \int_{-\infty}^{\infty} \mathrm{h}\left(\tilde{Q} \mid x_{s l}\right) \cdot \mathrm{n}(\tilde{Q}) d \tilde{Q}-\left(1-\mathrm{q}\left(x_{s l}\right)\right) \int_{-\infty}^{\infty} \partial \mathrm{h}\left(\tilde{Q} \mid x_{s l}\right) / \partial x \cdot \mathrm{n}(\tilde{Q}) d \tilde{Q}$

will hold when $\sigma$ is great. That is, it is more likely that the audit effort level under negligence liability is higher than under strict liability when the variance of the legal error is large.

We next analyze a firm owner's auditor hiring and investment decisions. Since $x_{n l}$ is the solution to (5),

$\mathrm{C}\left(x_{n l}\right)+(1-p)\left(1-\mathrm{q}\left(x_{n l}\right)\right)(I-B) \int_{-\infty}^{\infty} \mathrm{h}\left(\tilde{Q} \mid x_{n l}\right) \cdot \mathrm{n}(\tilde{Q}) d \tilde{Q}$

is less than

$\mathrm{C}\left(x_{s l}\right)+(1-p)\left(1-\mathrm{q}\left(x_{s l}\right)\right)(I-B) \int_{-\infty}^{\infty} \mathrm{h}\left(\tilde{Q} \mid x_{s l}\right) \cdot \mathrm{n}(\tilde{Q}) d \tilde{Q}$.

The latter is less than $\mathrm{C}\left(x_{s l}\right)+(1-p)\left(1-\mathrm{q}\left(x_{s l}\right)\right)(I-B)$. Thus,

$$
\begin{aligned}
\mathrm{C}\left(x_{n l}\right)+(1-p)\left(1-\mathrm{q}\left(x_{n l}\right)\right)(I-B) \int_{-\infty}^{\infty} \mathrm{h}\left(\tilde{Q} \mid x_{n l}\right) \cdot \mathrm{n}(\tilde{Q}) d \tilde{Q}<\mathrm{C}\left(x_{s l}\right) \\
+(1-p)\left(1-\mathrm{q}\left(x_{s l}\right)\right)(I-B) .
\end{aligned}
$$

Assuming a perfectly competitive audit market,

$\mathrm{C}\left(x_{n l}\right)+(1-p)\left(1-\mathrm{q}\left(x_{n l}\right)\right)(I-B) \int_{-\infty}^{\infty} \mathrm{h}\left(\tilde{Q} \mid x_{n l}\right) \cdot \mathrm{n}(\tilde{Q}) d \tilde{Q}$

and $\mathrm{C}\left(x_{s l}\right)+(1-p)\left(1-\mathrm{q}\left(x_{s l}\right)\right)(I-B)$ are also the audit fees under negligence liability and strict liability, respectively. Hence, the equilibrium audit fee is higher under strict liability. One may tend to conclude that the higher audit fee under strict 
liability would cause fewer firm owners to hire auditors and fewer investments to be undertaken under strict liability than under negligence liability. However, this conjecture is not necessarily correct. In what follows, we show that a firm owner's expected benefit from an audit is higher under strict liability. In addition, the expected number of investments undertaken can also be greater as a consequence.

Noted that, given audit effort $x$, the expected price of a firm under negligence liability is

$[p+(1-p)(1-\mathrm{q}(x))]$

$$
\left\{\frac{p G+(1-p)(1-\mathrm{q}(x))\left[B+(I-B) \int_{-\infty}^{\infty} \mathrm{h}(\tilde{Q} \mid x) \cdot n(\tilde{Q}) d \tilde{Q}\right]}{p+(1-p)(1-\mathrm{q}(x))}-I\right\},
$$

which can be restated as

$E-I+(1-p)(I-B)\left[\mathrm{q}(x)+(1-\mathrm{q}(x)) \int_{-\infty}^{\infty} \mathrm{h}(\tilde{Q} \mid x) \cdot \mathrm{n}(\tilde{Q}) d \tilde{Q}\right]$.

This is less than the one under strict liability, $E-I+(1-p)(I-B)$, due to smaller expected damage awards from the auditor under negligence liability. However, the difference in the expected prices of the firm is exactly offset by the difference in the audit fees (that is,

$\mathrm{C}(x)+(1-p)(1-\mathrm{q}(x))(I-B) \int_{-\infty}^{\infty} \mathrm{h}(\tilde{Q} \mid x) \cdot \mathrm{n}(\tilde{Q}) d \tilde{Q}$

under negligence liability versus $\mathrm{C}(x)+(1-p)(1-\mathrm{q}(x))(I-B)$ under strict liability). Hence, given audit effort $x$, the firm owner's expected benefit from an audit is the same under the two liability regimes and equals $E-I+\mathrm{q}(x)(1-p)(I-B)$ $-\mathrm{C}(x)$. Furthermore, both the firm owner's auditor-hiring decisions and the expected number of investments undertaken are also the same across the two liability regimes. Therefore, the real difference between strict liability and negligence liability can occur only when an auditor's effort decisions are different across the two regimes.

Let $\mathrm{W}(x) \equiv E-I+\mathrm{q}(x)(1-p)(I-B)-\mathrm{C}(x)$ be a firm owner's expected benefit from an audit, given audit effort $x$. $\mathrm{W}(x)$ is maximized when $\mathrm{q}^{\prime}(x)(1-p)$ $(I-B)-\mathrm{C}^{\prime}(x)=0$. Equations (4) and (6) imply that a firm owner's expected benefit from an audit achieves its maximum under strict liability and thus $\mathrm{W}\left(x_{n l}\right)$ $\leq \mathrm{W}\left(x_{s l}\right)$. Therefore, for firms with $\mathrm{W}\left(x_{n l}\right)<0 \leq \mathrm{W}\left(x_{s l}\right)$, the owners do not hire auditors under negligence liability but choose to do so under strict liability.

To examine the expected number of investments being undertaken under the two liability regimes, we divide all firms into two groups: firms with 
$\mathrm{q}^{\prime}\left(x_{s l}\right)<\mathrm{q}^{\prime}\left(x_{s l}\right) \int_{-\infty}^{\infty} \mathrm{h}\left(\tilde{Q} \mid x_{s l}\right) \cdot \mathrm{n}(\tilde{Q}) d \tilde{Q}-\left(1-\mathrm{q}\left(x_{s l}\right)\right) \int_{-\infty}^{\infty} \partial \mathrm{h}\left(\tilde{Q} \mid x_{s l}\right) /$ $\partial x \cdot \mathrm{n}(\tilde{Q}) d \tilde{Q}$

and firms with

$$
\begin{array}{r}
\mathrm{q}^{\prime}\left(x_{s l}\right) \geq \mathrm{q}^{\prime}\left(x_{s l}\right) \int_{-\infty}^{\infty} \mathrm{h}\left(\tilde{Q} \mid x_{s l}\right) \cdot \mathrm{n}(\tilde{Q}) d \tilde{Q}-\left(1-\mathrm{q}\left(x_{s l}\right)\right) \int_{-\infty}^{\infty} \partial \mathrm{h}\left(\tilde{Q} \mid x_{s l}\right) / \\
\partial x \cdot \mathrm{n}(\tilde{Q}) d \tilde{Q} .
\end{array}
$$

For the former group, the audit effort is lower under strict liability. Consequently, the likelihood that a firm owner receives an unqualified opinion is higher and more firms can get financed under strict liability. Thus, the expected number of investments undertaken is greater under strict liability for firms with

$$
\begin{array}{r}
\mathrm{q}^{\prime}\left(x_{s l}\right)<\mathrm{q}^{\prime}\left(x_{s l}\right) \int_{-\infty}^{\infty} \mathrm{h}\left(\tilde{Q} \mid x_{s l}\right) \cdot \mathrm{n}(\tilde{Q}) d \tilde{Q}-\left(1-\mathrm{q}\left(x_{s l}\right)\right) \int_{-\infty}^{\infty} \partial \mathrm{h}\left(\tilde{Q} \mid x_{s l}\right) / \\
\partial x \cdot \mathrm{n}(\tilde{Q}) d \tilde{Q} .
\end{array}
$$

There are two reasons for this: (1) for firms that hire auditors under both liability regimes, the probability of receiving an unqualified opinion is higher under strict liability, and (2) some firm owners who do not hire auditors under negligence liability choose to do so under strict liability. On the other hand, for firms with

$$
\begin{array}{r}
\mathrm{q}^{\prime}\left(x_{s l}\right) \geq \mathrm{q}^{\prime}\left(x_{s l}\right) \int_{-\infty}^{\infty} \mathrm{h}\left(\tilde{Q} \mid x_{s l}\right) \cdot \mathrm{n}(\tilde{Q}) d \tilde{Q}-\left(1-\mathrm{q}\left(x_{s l}\right)\right) \int_{-\infty}^{\infty} \partial \mathrm{h}\left(\tilde{Q} \mid x_{s l}\right) / \\
\partial x \cdot \mathrm{n}(\tilde{Q}) d \tilde{Q},
\end{array}
$$

the audit effort is higher under strict liability. Hence, the probability that these firms will receive a qualified opinion is higher under strict liability. This in turn decreases the probability that they will undertake the investment opportunity. Therefore, for firms with

$$
\begin{array}{r}
\mathrm{q}^{\prime}\left(x_{s l}\right) \geq \mathrm{q}^{\prime}\left(x_{s l}\right) \int_{-\infty}^{\infty} \mathrm{h}\left(\tilde{Q} \mid x_{s l}\right) \cdot \mathrm{n}(\tilde{Q}) d \tilde{Q}-\left(1-\mathrm{q}\left(x_{s l}\right)\right) \int_{-\infty}^{\infty} \partial \mathrm{h}\left(\tilde{Q} \mid x_{s l}\right) / \\
\partial x \cdot \mathrm{n}(\tilde{Q}) d \tilde{Q},
\end{array}
$$

the expected number of investments undertaken can be either greater or less under strict liability, which depends on the relative magnitudes of two opposite forces: (1) for firms that hire auditors under both liability regimes, the probability of receiving a qualified opinion is higher under strict liability, and (2) some firm owners who do not hire auditors under negligence liability choose to do so under strict liability. The former will reduce the expected number of investments undertaken, while the latter will increase it. 
The above discussion on the differences between negligence liability and strict liability with respect to the audit and initial public offering (IPO) market equilibrium can be summarized as Proposition 2 .

PROPOSITION 2. Compared with the equilibrium under strict liability, the equilibrium under negligence liability is characterized as follows:

(a) Audit fees: The audit fee under negligence liability is

$$
C\left(x_{n l}\right)+(1-p)\left(1-\mathrm{q}\left(x_{n l}\right)\right)(I-B) \int_{-\infty}^{\infty} \mathrm{h}\left(\tilde{Q} \mid x_{n l}\right) \cdot \mathrm{n}(\tilde{Q}) d \tilde{Q},
$$

which is lower than that under strict liability, $C\left(x_{s l}\right)+(1-p)$ $\left(1-\mathrm{q}\left(x_{s l}\right)\right)(I-B)$.

(b) Audit effort: The larger the variance of the legal error, the more likely that $x_{n l}>x_{s l}$. Auditors' effort levels are lower under negligence liability for firms with

$$
\begin{aligned}
\mathrm{q}^{\prime}\left(x_{s l}\right) \geq \mathrm{q}^{\prime}\left(x_{s l}\right) \int_{-\infty}^{\infty} \mathrm{h}\left(\tilde{Q} \mid x_{s l}\right) \cdot \mathrm{n}(\tilde{Q}) d \tilde{Q}-\left(1-\mathrm{q}\left(x_{s l}\right)\right) \\
\\
\int_{-\infty}^{\infty} \partial \mathrm{h}\left(\tilde{Q} \mid x_{s l}\right) / \partial x \cdot \mathrm{n}(\tilde{Q}) d \tilde{Q}
\end{aligned}
$$

and higher under negligence liability for firms with

$$
\begin{aligned}
\mathrm{q}^{\prime}\left(x_{s l}\right)<\mathrm{q}^{\prime}\left(x_{s l}\right) \int_{-\infty}^{\infty} \mathrm{h}\left(\tilde{Q} \mid x_{s l}\right) \cdot \mathrm{n}(\tilde{Q}) d \tilde{Q}-\left(1-\mathrm{q}\left(x_{s l}\right)\right) \\
\\
\int_{-\infty}^{\infty} \partial \mathrm{h}\left(\tilde{Q} \mid x_{s l}\right) / \partial x \cdot \mathrm{n}(\tilde{Q}) d \tilde{Q} .
\end{aligned}
$$

(c) Auditor-hiring decision: A firm owner's expected benefit from an audit is lower under negligence liability. That is, $\mathrm{W}\left(x_{n l}\right) \leq \mathrm{W}\left(x_{s l}\right)$. For firms with $0<\mathrm{W}\left(x_{n l}\right)<\mathrm{W}\left(x_{s l}\right)$, the owners will hire auditors under both liability regimes; for firms with $\mathrm{W}\left(x_{n l}\right)<\mathrm{W}\left(x_{s l}\right)<0$, no owner will hire an auditor under either liability regime; for firms with $\mathrm{W}\left(x_{n l}\right)<0 \leq \mathrm{W}\left(x_{s l}\right)$, the owners will hire auditors under strict liability but will not do so under negligence liability.

(d) Price of the firm: The expected price of a firm under negligence liability is

$$
\begin{aligned}
& E-I+(1-p)(I-B)\left[\mathrm{q}\left(x_{n l}\right)+\left(1-\mathrm{q}\left(x_{n l}\right)\right)\right. \\
& \left.\qquad \int_{-\infty}^{\infty} \mathrm{h}\left(\tilde{Q} \mid x_{n l}\right) \cdot \mathrm{n}(\tilde{Q}) d \tilde{Q}\right],
\end{aligned}
$$

which is less than that under strict liability, $E-I+(1-p)(I-B)$. 
(e) Audit opinion: The probability of receiving an unqualified opinion is higher under negligence liability for firms with

$$
\begin{aligned}
\mathrm{q}^{\prime}\left(x_{s l}\right) \geq \mathrm{q}^{\prime}\left(x_{s l}\right) \int_{-\infty}^{\infty} \mathrm{h}\left(\tilde{Q} \mid x_{s l}\right) \cdot \mathrm{n}(\tilde{Q}) d \tilde{Q}-\left(1-\mathrm{q}\left(x_{s l}\right)\right) \\
\\
\int_{-\infty}^{\infty} \partial \mathrm{h}\left(\tilde{Q} \mid x_{s l}\right) / \partial x \cdot \mathrm{n}(\tilde{Q}) d \tilde{Q}
\end{aligned}
$$

and is lower under negligence liability for firms with

$$
\begin{aligned}
\mathrm{q}^{\prime}\left(x_{s l}\right)<\mathrm{q}^{\prime}\left(x_{s l}\right) \int_{-\infty}^{\infty} \mathrm{h}\left(\tilde{Q} \mid x_{s l}\right) \cdot \mathrm{n}(\tilde{Q}) d \tilde{Q}-\left(1-\mathrm{q}\left(x_{s l}\right)\right) \\
\\
\quad \int_{-\infty}^{\infty} \partial \mathrm{h}\left(\tilde{Q} \mid x_{s l}\right) / \partial x \cdot \mathrm{n}(\tilde{Q}) d \tilde{Q} .
\end{aligned}
$$

(f) Investment decision: The expected number of investments being undertaken under negligence liability is less for firms with

$$
\begin{aligned}
\mathrm{q}^{\prime}\left(x_{s l}\right)<\mathrm{q}^{\prime}\left(x_{s l}\right) \int_{-\infty}^{\infty} \mathrm{h}\left(\tilde{Q} \mid x_{s l}\right) \cdot \mathrm{n}(\tilde{Q}) d \tilde{Q}-\left(1-\mathrm{q}\left(x_{s l}\right)\right) \\
\\
\int_{-\infty}^{\infty} \partial \mathrm{h}\left(\tilde{Q} \mid x_{s l}\right) / \partial x \cdot \mathrm{n}(\tilde{Q}) d \tilde{Q}
\end{aligned}
$$

and could be less, the same, or greater for firms with

$$
\begin{aligned}
\mathrm{q}^{\prime}\left(x_{s l}\right) \geq \mathrm{q}^{\prime}\left(x_{s l}\right) \int_{-\infty}^{\infty} \mathrm{h}\left(\tilde{Q} \mid x_{s l}\right) \cdot \mathrm{n}(\tilde{Q}) d \tilde{Q}-\left(1-\mathrm{q}\left(x_{s l}\right)\right) \\
\int_{-\infty}^{\infty} \partial \mathrm{h}\left(\tilde{Q} \mid x_{s l}\right) / \partial x \cdot \mathrm{n}(\tilde{Q}) d \tilde{Q} .
\end{aligned}
$$

Finally, the social welfare under the two liability regimes can be analyzed as follows. Since both capital and audit markets are competitive, each of the new investors and the auditors earns zero expected profits and the social welfare equals the firm owner's expected benefit from an audit. Proposition 2(c) indicates that strict liability improves social welfare because the firm owner's expected benefit is greater. Specifically, when the variance of the legal error is relatively large, it is more likely that

$$
\begin{array}{r}
\mathrm{q}^{\prime}\left(x_{s l}\right)<\mathrm{q}^{\prime}\left(x_{s l}\right) \int_{-\infty}^{\infty} \mathrm{h}\left(\tilde{Q} \mid x_{s l}\right) \cdot \mathrm{n}(\tilde{Q}) d \tilde{Q}-\left(1-\mathrm{q}\left(x_{s l}\right)\right) \int_{-\infty}^{\infty} \partial \mathrm{h}\left(\tilde{Q} \mid x_{s l}\right) / \\
\\
\partial x \cdot \mathrm{n}(\tilde{Q}) d \tilde{Q} .
\end{array}
$$

An auditor has incentive to exert more effort to avoid the high possibility of damage payment due to a possibly low effort assessed by the court under negligence liability. The strict liability regime eliminates the over-auditing phenomenon because 
no judgement is required. On the other hand, when the variance of the legal error is relatively small, it is more likely that

$$
\begin{aligned}
& \mathrm{q}^{\prime}\left(x_{s l}\right) \geq \mathrm{q}^{\prime}\left(x_{s l}\right) \int_{-\infty}^{\infty} \mathrm{h}\left(\tilde{Q} \mid x_{s l}\right) \cdot \mathrm{n}(\tilde{Q}) d \tilde{Q}-\left(1-\mathrm{q}\left(x_{s l}\right)\right) \int_{-\infty}^{\infty} \partial \mathrm{h}\left(\tilde{Q} \mid x_{s l}\right) / \\
& \partial x \cdot \mathrm{n}(\tilde{Q}) d \tilde{Q} .
\end{aligned}
$$

An auditor has less incentive to make an effort under negligence liability because the court is relatively precise in assessing an auditor's effort level and the auditor is not always liable for the investor's loss under negligence liability. Thus, the social welfare can be improved by inducing more audit effort. The strict liability regime eliminates the under-auditing phenomenon because it lines up an auditor's effort decision with the one that maximizes social welfare (that is, $x_{s l}=x^{*}$ ). ${ }^{10}$

\section{Conclusion}

This paper compares the equilibria under two auditor liability regimes: strict liability and negligence liability. It is shown that the firm owner is better off and more audits are performed under strict liability. If the variance of the legal error under negligence liability is large enough, it could give auditors more incentive to make an effort under negligence liability. However, the expected number of investments being undertaken can be greater or less under strict liability. Hence, our results do not support the claim made by some public accountants that the increase in auditor liability will result in firms' inability to afford a high audit fee and hence investment opportunities will be abandoned. The reason is that the claim focuses only on the increase in audit fees caused by the increase in auditor liability, but ignores the increase in investors' damage awards from the auditor. That is, higher auditor liability results in higher value of the investment to an investor. Hence, the expected number of the investments undertaken will not decrease due to the increase in audit fees. On the contrary, more auditors are hired under strict liability. The expected number of investments undertaken could be lowered only because of the increase in probability that worthless investment opportunities are revealed by the qualified audit opinion.

Furthermore, our results can be applied to predict the effects of the change in auditor liability in various legal environments. For countries with a small legalerror variance, negligence liability gives an auditor less incentive to work hard. Hence, the change to strict liability would increase an auditor's incentive to work. In contrast, for countries with a large legal-error variance, the uncertainty of the legal system gives an auditor incentive to work harder to avoid the possible adverse judgement. Thus, an auditor's incentive to make an effort will be reduced by shifting to strict liability.

Finally, it should be noted that the audit market is assumed to be competitive so that the auditors earn zero economic profit in equilibrium. An auditor a priori will have no preference for one liability regime over the other. Therefore, the setting considered in this paper cannot analyze the effects of the change in the liability regime on an auditor's profit and cannot explain an auditor's attitude toward different 
liability regimes. To study an auditor's preference across different liability regimes, one must know how the benefit of an audit is allocated between the firm owner and the auditor, supposing it is legitimate to assume a competitive IPO market where investors will not share extra benefit from undertaking an investment. One must make specific assumptions about the relative bargaining powers between the two parties or the relative numbers of auditors and each type of firms, which will significantly complicate the analysis. We leave a rigorous treatment of this issue for future research.

\section{Appendix}

\section{Proof of Lemma 1}

Recall that

$\mathrm{h}(\tilde{Q} \mid x)=\frac{1}{\sqrt{2 \pi} \sigma} e^{-\frac{(\tilde{Q}-x)^{2}}{2 \sigma^{2}}}$.

Hence,

$$
\begin{aligned}
& \frac{\partial \mathrm{h}(\tilde{Q} \mid x)}{\partial \sigma}=\frac{1}{\sqrt{2 \pi} \sigma^{4}}\left[(\tilde{Q}-x)^{2}-\sigma^{2}\right] e^{-\frac{(\tilde{Q}-x)^{2}}{2 \sigma^{2}}}, \\
& \frac{\partial \mathrm{h}(\tilde{Q} \mid x)}{\partial x}=\frac{\tilde{Q}-x}{\sqrt{2 \pi} \sigma^{3}} e^{\frac{(\tilde{Q}-x)^{2}}{2 \sigma^{2}}}
\end{aligned}
$$

and

$$
\begin{aligned}
& \frac{\partial^{2} \mathrm{~h}(\tilde{Q} \mid x)}{\partial x \partial \sigma}=\frac{1}{\sqrt{2 \pi}}\left[\frac{(\tilde{Q}-x)^{3}}{\sigma^{6}}-\frac{3(\tilde{Q}-x)}{\sigma^{4}}\right] e^{-\frac{(\tilde{Q}-x)^{2}}{2 \sigma^{2}}} \\
& \partial\left[\mathrm{q}^{\prime}(x) \int_{-\infty}^{\infty} \mathrm{h}(\tilde{Q} \mid x) \cdot \mathrm{n}(\tilde{Q}) d \tilde{Q}-(1-\mathrm{q}(x)) \int_{-\infty}^{\infty} \frac{\partial \mathrm{h}(\tilde{Q} \mid x)}{\partial x} \cdot \mathrm{n}(\tilde{Q}) d \tilde{Q}\right] / \partial \sigma \\
& =\mathrm{q}^{\prime}(x) \int_{-\infty}^{\infty} \frac{\partial \mathrm{h}(\tilde{Q} \mid x)}{\partial x} \cdot \mathrm{n}(\tilde{Q}) d \tilde{Q}-(1-\mathrm{q}(x)) \int_{-\infty}^{\infty} \frac{\partial^{2} \mathrm{~h}(\tilde{Q} \mid x)}{\partial x \partial \sigma} \cdot \mathrm{n}(\tilde{Q}) d \tilde{Q}
\end{aligned}
$$




$$
\begin{aligned}
&=\mathrm{q}^{\prime}(x) \int_{-\infty}^{\infty} \frac{\left[(\tilde{Q}-x)^{2}-\sigma^{2}\right]}{\sqrt{2 \pi} \sigma^{4}} e^{-\frac{(\tilde{Q}-x)^{2}}{2 \sigma^{2}}} \mathrm{n}(\tilde{Q}) d \tilde{Q} \\
&-(1-\mathrm{q}(x)) \int_{-\infty}^{\infty} \frac{1}{\sqrt{2 \pi}}\left[\frac{(\tilde{Q}-x)^{3}}{\sigma^{6}}-\frac{3(\tilde{Q}-x)}{\sigma^{4}}\right] e^{-\frac{(\tilde{Q}-x)^{2}}{2 \sigma^{2}}} \mathrm{n}(\tilde{Q}) d \tilde{Q} .
\end{aligned}
$$

With integration by parts, it can be shown that

$$
\begin{array}{r}
\partial\left[\mathrm{q}^{\prime}(x) \int_{-\infty}^{\infty} \mathrm{h}(\tilde{Q} \mid x) \cdot \mathrm{n}(\tilde{Q}) d \tilde{Q}-(1-\mathrm{q}(x)) \int_{-\infty}^{\infty} \frac{\partial \mathrm{h}(\tilde{Q} \mid x)}{\partial x} \cdot \mathrm{n}(\tilde{Q}) d \tilde{Q}\right] / \partial \sigma \\
=\int_{-\infty}^{\infty} \mathrm{n}^{\prime \prime}(\tilde{Q}) \frac{1}{\sqrt{2 \pi}} e^{-\frac{(\tilde{Q}-x)^{2}}{2 \sigma^{2}}} d \tilde{Q} .
\end{array}
$$

Thus,

$\partial\left[\mathrm{q}^{\prime}(x) \int_{-\infty}^{\infty} \mathrm{h}(\tilde{Q} \mid x) \cdot \mathrm{n}(\tilde{Q}) d \tilde{Q}-(1-\mathrm{q}(x)) \int_{-\infty}^{\infty} \frac{\partial \mathrm{h}(\tilde{Q} \mid x)}{\partial x} \cdot \mathrm{n}(\tilde{Q}) d \tilde{Q}\right] / \partial \sigma>0$

since $\mathrm{n}^{\prime \prime}(\tilde{Q})>0$.

\section{Endnotes}

1. For example, see Dye 1993, 1995; Narayanan 1994; Chan and Pae 1998; Radhakrishnan 1999; and Pae and Yoo 2001.

2. In the United States, the 2002 Sarbanes-Oxley Act increased the penalties for corporate crimes. In Germany, the 1998 Gesetz zur Kontrolle und Transparenz im Unternehmensbereich increased the maximum damage payments for each false statement from 0.5 to 8 million DM.

3. A firm with positive ex ante expected net return (that is, $E-I>0$ ) can always get financed by not hiring an auditor if an audit is not mandatory. However, it is impossible for a firm with $E-I<0$ to obtain funds without an audit. Therefore, an audit plays a more important role for firms with $E-I<0$. In this paper, we do not restrict the relative magnitudes between $E$ and $I$. However, if we focus on the case $E-I<0$, it can be shown that the number of investments being undertaken can be greater and the firm owners are always better off under strict liability than under negligence liability. Thus, the results of this paper remain valid.

4. It can be shown that the main conclusions still hold in the absence of the mandatory audit requirement.

5. In the analytical literature in auditing, it is typically assumed that an auditor does not make a type I error (e.g., Melumad and Thoman 1990a, b; Dye 1993, 1995; Narayanan 
1994; Schwartz 1997; Chan and Pae 1998; Frantz 1999; Hillegeist 1999; Radhakrishnan 1999; Lee, Liu, and Wang 1999; Zhang and Thoman 1999; Pae and Yoo 2001; Chan and Wong 2002). For analysis involving a strategic type I error, see Patterson 1993 and Shibano 2000.

6. The results of this paper still hold if we assume that the investor will sue the auditor with some probability $s \in[0,1]$ when an audit failure occurs.

7. Note that the strict liability regime is equivalent to the negligence liability regime with $\mathrm{n}(\tilde{Q})=1$ for all $\tilde{Q}$. To differentiate the two regimes, we rule out this case under negligence liability.

8. To ensure that the audit effort satisfying the first-order condition is indeed the unique solution, we assume that $\mathrm{C}^{\prime \prime}(x)-\mathrm{q}^{\prime \prime}(x)(1-p)(I-B)>0$ for all $x$.

9. It can be shown that the second-order condition of (5) is satisfied under the assumption in endnote 8.

10. Even though it is shown that the auditor's effort decision is socially optimal under strict liability, while in general this is not true under negligence liability, critics may allege that the model in this paper is too simple to portray the real world. Indeed, the optimality of the strict liability rule may be affected by the risk attitude of the players, the existence of punitive damage awards, the existence of multiple tortfeasors, and so on. Specifically, if the auditor is risk-averse, the audit effort determined by an auditor's expected utility maximization problem will, in general, not be equal to the one that maximizes the social welfare. However, if there exists an insurance market for the litigation risk, it can be shown that the strict liability rule is still efficient (see Shavell 1987). The magnitude of the liability will also affect the efficiency of the strict liability rule. In our model, if the auditor's liability payment is not $I-B$, say, due to the existence of punitive damage awards, it is straightforward to see that the audit effort under strict liability will in general not be optimal. Besides, if we extend our model to a multiparty liability problem where the probability that an auditor issues a qualified opinion depends on the effort levels of the manager and the auditor, then the audit effort level under strict liability will no longer be efficient.

\section{References}

Arthur Andersen \& Co., Coopers \& Lybrand, Deloitte \& Touche, Ernst \& Young, KPMG Peat Marwick, and Price Waterhouse. 1992. The liability crisis in the United States: Impact on the accounting profession. Journal of Accountancy 174 (5): 18-23.

Chan, D. K., and S. Pae. 1998. An analysis of the economic consequences of the proportionate liability rule. Contemporary Accounting Research 15 (4): 457-80.

Chan, D. K., and K. P. Wong. 2002. Scope of auditors' liability, audit quality, and capital investment. Review of Accounting Studies 7 (1): 97-122.

Coffee, J. C., Jr. 2004. Gatekeeper failure and reform: The challenge of fashioning relevant reforms. Boston University Law Review 84 (2): 301-64.

Dye, R. 1993. Auditing standards, legal liability, and auditor wealth. Journal of Political Economy 101 (5): 887-914.

Dye, R. 1995. Incorporation and the audit markets. Journal of Accounting and Economics 19 (1): 75-114. 
Ewert, R., E. Feess, and M. Nell. 2000. Auditor liability rules under imperfect information and costly litigation: The welfare-increasing effect of liability insurance. European Accounting Review 9 (3): 371-85.

Frantz, P. 1999. Auditor's skill, auditing standards, litigation, and audit quality. British Accounting Review 31 (2): 151-83.

Ginsburg, J. C. 1995. Putting cars on the "information superhighway": Authors, exploiters, and copyright in cyberspace. Columbia Law Review 95 (2): 1466-99.

Hamdani, A. 2003. Gatekeeper liability. Southern California Law Review 77 (1): 53-121.

Hardy, I. T. 1994. The proper legal regime for "cyberspace". University of Pittsburgh Law Review 55 (4): 993-1055.

Hillegeist, S. A. 1999. Financial reporting and auditing under alternative damage apportionment rules. The Accounting Review 74 (4): 347-69.

Lee, C. J., C. Liu, and T. Wang. 1999. The 150-hour rule. Journal of Accounting and Economics 27 (2): 203-28.

Melumad, N., and L. Thoman. 1990a. An equilibrium analysis of optimal audit contracts. Contemporary Accounting Research 7 (1): 22-55.

Melumad, N., and L. Thoman. 1990b. On auditors and the courts in an adverse selection setting. Journal of Accounting Research 28 (1): 77-120.

Narayanan, V. G. 1994. An analysis of auditor liability rules. Journal of Accounting Research 32 (Supplement): 39-59.

Pae, S., and S. Yoo. 2001. Strategic interaction in auditing: An analysis of auditors' legal liability, internal control system quality, and audit effort. The Accounting Review 76 (3): 333-56.

Partnoy, F. 2001. Barbarians at the gatekeepers? A proposal for a modified strict liability regime. Washington University Law Quarterly 79 (2): 491-547.

Patterson, E. R. 1993. Strategic sample size choice in auditing. Journal of Accounting Research 31 (2): 272-93.

Radhakrishnan, S. 1999. Investors' recovery friction and auditor liability rules. The Accounting Review 74 (2): 225-40.

Schwartz, R. 1997. Legal regimes, audit quality and investment. The Accounting Review 72 (3): 385-406.

Shavell, S. 1980. Strict liability versus negligence. Journal of Legal Studies 9 (1): 1-25.

Shavell, S. 1987. Economic analysis of accident law. Cambridge, MA: Harvard University Press.

Shibano, T. 2000. Overguarding the guardians: Increasing auditor liability decreases new investments. Working paper, University of Chicago.

Yen, A. C. 2000. Internet service provider liability for subscriber copyright infringement, enterprise liability and the first amendment. Georgetown Law Journal 88 (6): 1833-2000.

Zhang, P., and L. Thoman. 1999. Pre-trial settlement and the value of audits. The Accounting Review 74 (4): 473-91. 
Copyright of Contemporary Accounting Research is the property of Canadian Academic Accounting Association and its content may not be copied or emailed to multiple sites or posted to a listserv without the copyright holder's express written permission. However, users may print, download, or email articles for individual use. 